(10 c. cm.) were then given twice a day. An immediate improvement followed, which continued till August 4th, when the injections were finally stopped. The patient has since stated that he "felt a new man" after each of the latter injections of which he was conscious. The lungs cleared up with but little expectoration.

It will be seen that the serum was mostly given in large doses, and that the larger doses produced more beneficial results than the small. The injections were made in the abdomen and loin. We noticed that the last half of the 20-c.cm. bottles which were opened in the morning produced a local erythema when injected in the evening, although the serum was kept in the interval in ice, and every precaution was taken to sterilise the site of injection and the syringe. The intensely hot weather may have had something to do with this.

In another case we should use a freshly-opened bottle for each injection, and would recommend that the serum be bottled in ro-c.cm. bottles with india-rubber corks. Two days after the injections were discontinued some urticaria gave a little trouble, but did not retard recovery, and, as the patient is now (August 19th) able to walk about his room and take drives, we feel we ought not to delay in placing these notes before the profession.

\section{CASE OF TETANUS TREATED WITH ANTITOXIN.}

BY J. J. RIDGE, M.D., B.S.LoND., Physician, London Temperance Hospital.

Or September 24th, 1895, H. H., aged 16, had his right hand caught between cogwheels, which tore off the skin between the fingers and thumb, and contused the muscles; the bones were not injured. The wound was dressed with carbolic oil.

All went well for thirteen days, but on October 7 th he began to complain of slight stiffness of the jaws and pain in the centre of the back. He was ordered chloral, gr.x three times a day.

On October gth he was sleeping well, and had taken food, but could not masticate on account of spasm.

On October roth the tongue was very sore on the left side (probably bitten), but he could not open his teeth more than half an inch. Pain in back varied, but he was able to walk. The bowels were very costive.

On October I 3 th he complained of pain in the abdomen, and had some spasmodic starts. The other symptoms were the same, but he was confined to bed.

On October $15^{\text {th }}$, at 5.30 A.M., the symptoms were aggravated he was restless with spasms, retraction of the head, opisthotonos and risus sardonicus. The abdomen was tense. One gramme of tetanus antitoxin, supplied by the British Institute of Preventive Medicine through Messrs. Allen and Hanburys, was injected, and the chloral stopped. He was a little quieter from 8 A.M. to 12, but many spasms occurred afterwards: he took liquid food well. The temperature was $100.2^{\circ}$. The injection was repeated at 5 P.M.; at II P.M. he was much the same. He had had many spasms. A third injection was given.

On October 16, at 8 A.M., he said he had less pain, and the spasms were not quite so frequent. He was perspiring freely, but was otherwise the same; temperature $10^{\circ}$; a fourth injection was given. At 3 P.M. he was much the same; temperature 101 $4^{\circ}$; and a fifth injection was given. At ro P.M. the spasms were about as.frequent, but not quite so strong. He said they were not nearly so painful. He took liquid food and swallowed well, but had not slept for some time. Temperature $100.6^{\circ}$. A sixth injection was given, and chloral gr.xxx.

On October I 1 th, at 8 A.M., it was found that he had slept a good deal in the night, with less spasm, but some had occurred during sleep; their severity varied. There had been some epistaxis. Temperature ror ${ }^{\circ}$. A seventh injection was given. At 3 P.M. he had been quieter. There was a good deal of erythematous inflammation, with some tumefaction, round the site of each injection. He took fluid food well, but could not open his mouth, and attempts caused spasm. Tem. perature $101^{\circ}$. The eighth injection was given. At ro P.M. he had had some sharp spasms, but on the whole was quieter. He said the spasms were less painful and that some did not hurt him at all. Bowels acted slightly as the result of ol. ricini and enema. Temperature 101 $^{\circ}$. The ninth injection was given, and chloral gr. $\mathbf{x x x}$.

October 18th, 8 A.M. He had had epistaxis twice in the night. He could open his teeth half an inch. The arm was a good deal inflamed. Temperature 101.6\%, pulse 136 . The tenth injection was given, and chloral gr. $x x$ at night.

October I9th, 8 A.M. He had had a good deal of sleep, but some sharp spasms between 5 and 6 A.M. He still started a good deal on any provocation, and the abdomen was hard. The wound was healing. Temperature $100^{\circ}$. The eleventh injection was given. Io P.M. Has had a fair day; a good many slight spasms. Chloral gr. xx.

On October 2oth, at Io A.M., he remained the same; occasional spasms of varying intensity occurred, but none extreme. There was still much perspiration. Temperature I00.6 $6^{\circ}$, pulse 120. The twelfth injection was given. 9 P.M. Temperature $100^{\circ}$, pulse 140 . The inflammation of the arm was better. No chloral was given.

October 2 rst, 8 A.m. He was improving slowly. He could raise the arms and the head now, and draw up his knees, but had many starts and spasms. He slept a good deal without the chloral. Bowels acted better. Temperature 100, pulse 140. As the spasms were rather more severe in the evening, he had chloral gr. $x \times$ at 8 P.M. At Io P.M. the temperature was $99.5^{\circ}$, and the thirteenth injection was given. He had a fair night, and on October 22nd, at 8 A.M., the temperature was $100^{\circ}$, pulse 128. At 9 A.M. he had a much quieter day till the evening, when there were several severe spasms. At 9 P.M. the temperature was $100^{\circ}$, and the pulse 132. Chloral gr. $\mathbf{x x}$ was ordered.

October 23 rd. The spasms varied, but he was quieter on the whole. The mouth was still contracted, and there was much urticaria round punctures. Temperature $100^{\circ}$, pulse 120. To take at night chloral gr. xx, pot. brom. gr. xxx. He slept more quietly; spasms now and then, sometimes rather sharp.

On October 24th he could not open his mouth; the spasms were worse when lying on his right side. The urine was now clear. Temperature $99.1^{\circ}$, pulse 128 . To take pot. brom. gr. $x$ 4 tis.

October 25th. He was still improving, but starts in his sleep. The mouth was still contracted. Temperature $98.4^{\circ}$, both morning and evening; pulse 124.

October 29th. Temperature had been normal since last report, pulse I20. He twitched in sleep, more when on his back. He could open the teeth one inch, and had slept better. The wound was healing quickly.

After this he made steady progress. The pulse came down very slowly.

With regard to the effect of the antitoxin, the first three or four injections did not seem to have any effect in stopping the spasms, but they did not get worse after they were commenced. After that there was decidedly an impression made. He had an injection three times a day (I gramme) for three days, and after that only once a day, as the chloral, then resumed, seemed to give considerable relief by sleep. The injections were made in various parts of all four extremities, as the amount of inflammation set up was very considerable, but all subsided ultimately without abscess. The frequency of the pulse continued for a remarkable time after the other symptoms subsided.

Telegony.-A hybrid between a male Burchell's zebra (Eguus Burchelli) and a mare (Equus Cabattus) has, we learn from Nature, been received at Professor Ewart's experimental stud at Penicuick, Midlothian. The mare is jet black, but the foal, except over the hind-quarters, has as many bands as its zebra parent. Should this mare now have a foal by an Arab stallion in the stud, much interest will be felt in the question whether this foal will present zebra stripes. It is well known that in a famous case this was asserted to have occurred, and the assertion was generally accepted until it was disputed in recent times by Professor Weissmann. Should the foal by an Arab stallion out of this mare be zebrastriped the occurrence will go far to justify the belief in telegony, or " the infection of the germ." 